\title{
Fra krisevalg til jordskredsvalg
}

Jørgen Goul Andersen og Ditte Shamshiri-Petersen (red.), 2016

Fra krisevalg til jordskredsvalg: Vælgere på vandring 2011-2015

Frydenlund Academic, Frederiksberg

383 sider, $299 \mathrm{kr}$.

Anmeldt af Erik Gahner Larsen

Fra krisevalg til jordskredsvalg: Voelgere på vandring 2011-2015 er ingenlunde en bog, der er nem at anmelde i én sammenhængende anmeldelse. Det skyldes, at der grundlæggende set er tale om to bøger i én. Forhåndenværende bog er på den ene side en antologi, hvor en lang række kyndige forskere og eksperter stiller skarpt på forskellige aspekter af vælgernes politiske overbevisninger, og på den anden side en traditionel monografi, hvor én forfatter gennem forskellige - men relaterede kapitler - belyser et overordnet tema. Bogen er på overfladen førstnævnte, men fungerer bedst som sidstnævnte.

Konteksten for bogen er perioden mellem 2011-valget, der stod i den økonomiske krises tegn, og 2015-valget, der bliver betegnet som et jordskredsvalg. Hvis man har interesse $\mathrm{i}$ at blive klogere på, hvad der er sket med vælgerne i denne periode, eller blot har en generel interesse for dansk politik, er der her tale om en bog, der bør læses.

Det er ellers ikke fordi, det skorter på bøger omhandlende de danske vælgeres politiske adfærd i løbet af de senere år. Således har vi relateret til folketingsvalget 2011 fået bøger som Krisevalg: Økonomien og folketingsvalget 2011 og Folketingsvalgkampen 2011 i perspektiv, der begge fokuserede på, hvordan vælgerne agerede op til og under 2011-valget. Ligeledes kommer der en bog om folketingsvalget 2015 i forbindelse med Det Danske Valgprojekt, så læsere med en særlig interesse for dette valg bliver heller ikke overset. Ikke desto mindre udfylder Fra krisevalg til jordskredsvalg et hul i markedet. Det er især grundet bogens eksplicitte fokus på det, der skete med vælgerne mellem de to seneste folketingsvalg. 
Heri ligger også bogens største svaghed, nemlig det forhold, at ikke alle kapitler passer lige godt ind i dette fokus. Der er således mange måder at læse bogen på, men der er ingen grund til at læse bogen fra første til sidste side. Til trods for at bogen giver indtryk af at beskæftige sig med vælgerne mellem to valg, er det ikke noget alle bogens forfattere fokuserer på, endsige forholder sig til. Den positive udlægning er, at det vil være svært at læse bogen fra første til sidste side uden at læse noget, der fanger ens interesse, hvis man er bare det mindste interesseret i politik.

\section{Én sammenhængende bog?}

I bogen er 13 af de 21 kapitler (med)forfattet af Jørgen Goul Andersen, og disse beskæftiger sig i de fleste tilfælde med perioden mellem valgene i 2011 og 2015. Disse kapitler fungerer godt sammen, hvorfor det også er uklart, hvorfor det ikke blot er disse 13 kapitler, der er skrevet til én sammenhængende bog. Kapitlerne har den fornødne kvalitet til at stå alene, og de andre kapitler, desuagtet den høje kvalitet flere af dem har, står primært i vejen for en samlet læseoplevelse.

Kapitlerne forfattet af Jørgen Goul Andersen er en minutiøs gennemgang af, hvad der skete med og i vælgerkorpset i perioden 2011-2015. Man kommer kort sagt ned i materien og bliver klogere på de danske vælgere. Kapitel 1 leverer et overordnet perspektiv med nogle grundlæggende ligheder og forskelle mellem 2011- og 2015-valget. Det er en fin introduktion, der formår at sætte rammen for resten af bogen. Fokus er på en analyse af partiernes - og især blokkenes - opbakning i perioden mellem de to valg. 2015-valget sættes her også i en historisk kontekst, hvor det vises, at vælgervolatiliteten er den højeste siden jordskredsvalget i 1973. Omvendt er kapitlet meget deskriptivt med et par overflødige tabeller, der mere har karakter af at være indhold til et opslagsværk end at formidle en pointe. Dette går desværre igen i flere af bogens kapitler. Ligeledes er der nogle aspekter, der med fordel kunne blive diskuteret mere fyldestgørende, og som ikke passer ind i resten af bogens fortælling, herunder hvordan Socialdemokraterne kan betegnes som et antireformparti i perioden 2011 til 2015.

En lang række af kapitlerne, mere specifikt kapitel 2, 3, 4, 7, 14, 16, 20 og 21, der alle har det tilfælles, at de ikke er (med)forfattet af Jørgen Goul Andersen, passer desværre ikke ind i den ramme, der sættes i det indledende kapitel. Fælles for disse kapitler 
er, at de ikke fokuserer på perioden efter 2011-valget. Det tætteste flere af kapitlerne kommer på dette er at anvende data, der er indsamlet op til eller under 2011-valget.

Kapitel 2 fokuserer på meningsmålingerne op til 2011-valget. Til dette anvendes udelukkende data fra Epinion, hvilket fungerer godt i gennemgangen af vælgernes opfattelse af de ni partiledere og analysen af tvivlerne, hvor der ikke er sammenlignelige data fra andre meningsmålingsinstitutter. Omvendt virker det, givet netop forekomsten af meningsmålinger fra flere institutter, som et unødigt afgrænsende fokus $i$ analysen af partiernes opbakning. Kapitel 3 bidrager med viden om, hvad vælgerne synes om valgkampen 2011. Dette kapitel bygger på kvalitative data indsamlet gennem nogle vælgeres valgdagbøger. Udfordringen for kapitlet er ikke de indsamlede data, men fraværet af en teoretisk ramme, der kan guide en kvalitativ analyse af de indsamlede data. Dette kapitel pointerer retmæssigt vigtigheden af at anvende mere end spørgeskemaundersøgelser for at kunne forstå vælgernes holdninger, men er desværre primært en potpourri af pessimistiske udmeldinger fra vælgerne om valgkampen, medierne, politikerne osv.

Kapitel 4 undersøger i hvilket omfang vælgerne tænker på samme måde som de politiske kommentatorer, altså om vælgeren agerer som en politisk kommentator, der ser spin alle vegne. Forfatterne finder først tydelige forskelle i, hvor udbredt strategispilsassociationer er blandt vælgerne, men det er mindre klart fra tolkningen af analysen, om det udvikler sig i løbet af valgkampen 2011. Først skrives der, at vælgerne får statistisk signifikant flere strategispilsassociationer, hvorefter det nævnes, at strategispilsassociationerne kun vokser med en procent, som ikke er statistisk signifikant. Sidst undersøges det, om strategispilsassociationer korrelerer med partivalg, men det står ikke klart efter endt læsning, om vi er blevet mere eller mindre kloge på verden, efter at være blevet præsenteret for disse korrelationsanalyser.

I kapitel 5 og 6 er vi tilbage til bogens hovedfokus. Kapitel 5 undersøger vælgervandringer og årsager hertil. Fokus er her på, hvilke partier vælgerne skiftede fra og til mellem de to valg. Til dette anvendes paneldata, der går igen i mange af bogens kapitler og giver nogle klare styrker i forhold til de fænomener, der kan belyses. Kapitel 6 fokuserer på, hvad klassiske (socio)demografiske forhold som køn, alder, klasse og bolig betød for sandsynligheden for at stemme på et socialistisk parti. Der er intet nyt under solen her, hvorfor dette forholdsvist lange kapitel nemt kan læses kursorisk. 
I kapitel 7 er vi igen væk fra bogens hovedfokus, og læseren skal forholde sig til værdipolitik i perioden 1990-2011, især med fokus på vigtigheden af værdipolitik vis-à-vis fordelingspolitik. En af de interessante pointer heri er, at vigtigheden af værdipolitik kan variere fra valg til valg. Således betød fordelingspolitik mere ved folketingsvalget i 2011, sandsynligvis på grund af den økonomiske krise. Dette overrasker nok de færreste, men pointerer, at det på ingen måde er afgjort på forhånd, hvad der bliver udslagsgivende for, hvor vælgerne sætter deres kryds ved et folketingsvalg.

I de efterfølgende kapitler er vi tilbage på hovedsporet og kigger på partivalg og politiske holdninger fra 2011 til 2015. I kapitel 8 vises det, at mange arbejdervælgere givetvis er gået mod højre, men deres holdninger er stadig venstreorienterede. Kapitel 9 kigger på holdningerne til flygtninge og de politiske implikationer heraf. Kapitel 10 belyser miljøpolitiske holdninger. Kapitel 11 undersøger relevansen af en konflikt mellem center og periferi med et særligt fokus på udkants-Danmark. Kapitel 12 kigger på vigtigheden af privatøkonomisk tryghed, kapitel 13 på vigtigheden af samfundsøkonomien.

I kapitel 14 diskuteres den del af velfærdslitteraturen, der beskæftiger sig med vælgernes respons til nedskæringer. Her er der primært fokus på perioden op til 2011valget, og især Venstres kursskifte i form af opgøret med Hjort-doktrinen. Der er tale om et ganske interessant kapitel, der dog som sagt ikke passer ind i bogens ramme, og som ligeledes ikke formår at perspektivere til anden relevant litteratur, der også har beskæftiget sig med især VK-regeringens efterlønsinitiativer. I kapitel 15 kigges der også på perioden op til 2011-valget med et fokus på hvilke emner, der var afgørende for, at vælgerne skiftede parti. Kapitel 16 belyser blokskiftere fra 2007 til 2011, hvor der både kigges på skift inden for og på tværs af rød og blå blok.

\section{Den politiske tillid i fokus}

En af de overordnede pointer, som bogen fremhæver - herunder også i pressematerialet, er, at vælgernes tillid til politikerne er rekordlav. Dette emne tages for alvor op i kapitel 17, hvor vælgernes politiske tillid behandles, både konceptuelt og begrebsmæssigt, i et komparativt perspektiv, over tid og med forskellige datasæt. Dette kapitel er med sine 43 sider klart det kvantitativt længste og kvalitativt mest gennemarbejdede. For alle læsere med en interesse for politisk (mis)tillid er dette kapitel ikke til at komme uden- 
om. Dette kapitel sætter ligeledes rammen for de næste to kapitler, hvori først vælgernes politiske mistillid og partiskift belyses i kapitel 18, og den politiske mistillids betydning ved EU-afstemningen i 2015 belyses i kapitel 19.

I de to sidste kapitler, kapitel 20 og 21, der tilsammen er på under 20 sider, er der nogle overordnede refleksioner om vælgervandringer og vælgerens politiske holdninger. Der er dog ingen klar disposition i disse kapitler, og det er begrænset, hvad man får ud af at læse disse, hvorfor disse også blot kan læses kursorisk. Ligeledes forspilder bogen her desværre dets mulighed for at bruge de sidste sider på at binde værket sammen til en helhed, der hjælper læseren med at konkludere på de mange forudgående kapitler. Bogen kommer vidt omkring, og dette fungerer fint for de dele af den, der passer ind i den overordnede ramme, men får desværre andre dele af bogen til at fremstå irrelevante og malplacerede. 